\title{
A REVIEW OF VARIOUS TECHNOLOGIES AND TRANSMISSION MODES FOR DESIGN AND DEVELOPMENT OF A TRANSMISSION ENABLED GLUCOMETER
}

\author{
B.G.Sudharshan ${ }^{1}$, S.C Prasanna Kumar ${ }^{2}$, Shashiraj Yadav R V \\ ${ }^{I}$ Professor, Dept of IT, RVCE, Bangalore, India \\ ${ }^{2} H O D$, Professor Dept of IT, RVCE, Bangalore, India \\ ${ }^{3}$ Dept of IT, RVCE, Bangalore, India
}

\begin{abstract}
This paper presents the various technologies used for design and development of the glucometer. It also focuses on Various parameters such as different data acquisition methods, various microcontrollers and also different transmission capabilities used are studied in detail. The transmission methods regularly adopted as per review are as follows 1.gsm 2.bluetooth 3.zigbee 4.wi-fi among these the best transmission capability was found in gsm. Available software's such as keil, c++compiler and SQL data base were also studied in detail to store and transmit the data. Different sensors for measurement of glucose was studied in detail which comprised of 1.amperometric sensors2.fibreoptic sensors 3.spectroscopic sensors among them amperometric sensors were found to be best suitable. Parameters such as data rate, range and complexity of the device are analysed.
\end{abstract}

\section{INTRODUCTION}

Diabetes is a chronic illness which requires regular monitoring of blood glucose levels, this monitoring helps in preventing complications. This will be fruitful if opinion can be taken by a doctor which is not easily possible owing to shortage of doctors especially in rural areas. This objective of patient doctor interaction can be achieved by glucometer having transmission capabilities.

\section{DIFFERENT METHODS OF APPROACH FOR}

\section{SENSING OF GLUCOSE}

The Data Acquisition Module (DAM) is composed a PIC microcontroller [3][6] and a GSM[9][10] module The microcontroller performs serial data transfer of patient's data from the medical device to the GSM module. It also acts as a temporary store for data acquired from medical devices in case of unavailability of GSM [11] services.

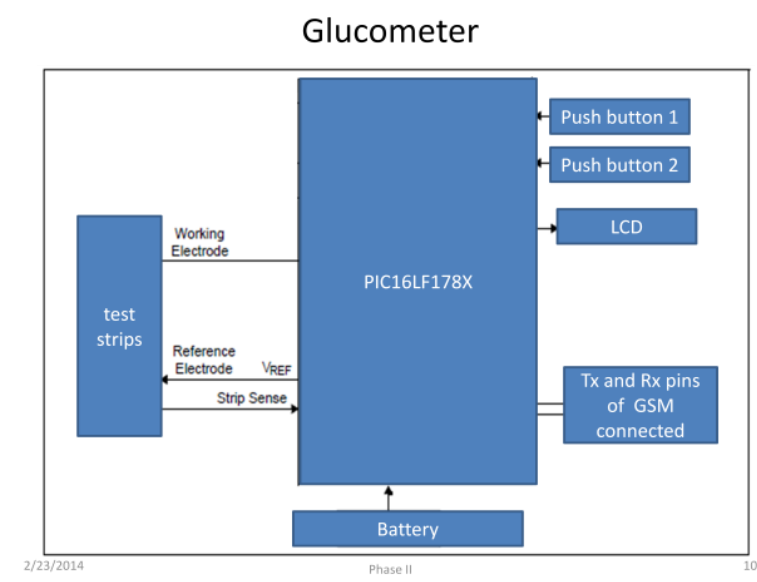

The GSM module used to transfer data acquired by the microcontroller to the doctor's mobile phone The TX and RX pins of the GSM module are initially connected to the microcontroller's Universal Asynchronous Receiver/ Transmitter (UART)[6]. Such a connection allows for serial data transfer [2][3] to the GSM module which will then transfer data to the patient's mobile. If the doctor cannot handle the situation the data will be sent to the health providers in super specialized hospital through the dbms software [1][20]

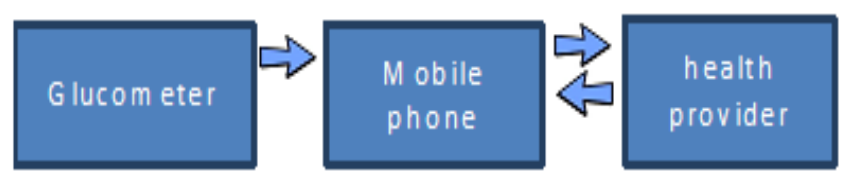

\section{AVAILABLE MICROCONTROLLERS}

A microcontroller is a small low cost and self contained computer that can be used as an embedded system. Usually they must have low power requirements since many devices that we control are battery operated. Hence well suited for long lasting battery applications the types of micro controller are characterized by their bits, memory and instruction set namely microcontroller 8051,AVR,PIC.[6] Usually 8051 consumes more power than AVR, we can program easily in AVR when compared with 8051, the speed of AVR is better than 8051 but when we see PIC they have much lower power consumption at 5v.usually PIC's code is completely efficient allowing typically less program memory than other microcontrollers. It is of low cost and has got high clock speed and has embedded A/D convertors and can be used in various medical applications such as 
glucometers sphygmomanometers, pulseoximeters, Digital thermometer, ECG.

\section{GLUCOSE SENSORS REVIEW}

Glucose sensors are developed based on different technology platforms such as

Amperometric Sensors [4][7][8] - an enzymatic electrochemical sensor was developed for continuos glucose monitoring based on a miniaturized[7]planar.the sensor was manufactured by using polymer film technology

Fibreoptic Sensors [4]- these sensors use the enzyme oxidation of glucose in combination with optical oxygen sensor as transducer. A fibre optic dual sensor setup was integrated into a flow through cell. one sensor measures oxygen only. while the second sensor is with an enzyme layer. the advantage of this approach is excellent selectivity of the oxygen optode transducer

Spectroscopic Glucose Sensor[7][8] - A mid infrared sensor for continuos glucose monitoring in combination with a subcutaneous or vascular body interfacewas developed to meet the demand for reagent free assays.the sensor is designed to ensure the utmost reliability need for ICU.

From the types of glucose sensors discussed above the constraint can be found in fibreoptic and spectroscopic sensors due to their level of accuracy. The level of accuracy is better in amperometric sensors[4][18] when compared with the other types

\section{VARIOUS WIRELESS TECHNOLOGIES}

The most common types of wireless technologies used are WI-FI - Almost everyone can access the internet in a given area but WI-FI still requires a internet connection this is then led to wireless router that sends and receives data to and from mobile devices depending on the strength of WI-FI signal this wireless technology can cover a single house[10][17] or even a whole school campus. To increase its range signal extenders are used[12][13]

Bluetooth - this has smallest area of effect.A Bluetooth connection only works with a few meters it is widely used to replace cables when transferring data.bluetooth is not ideal when it comes to transferring large amounts of data as it tends to be a slower and can consume a significant amount of power[12][16]

Zigbee[10]- it is widely used today in areas where low power consumption and low cost are absolutely necessary in area where Bluetooth[14][15] would have proven costlier and consumed greater power.zigbee will be able to eliminate the necessity of cables and wires[9][10]

GSM -it usually operates in the 900 and $1800 \mathrm{MHz}$ bands.thegsm user will use sim cards for the connection with the service provider.sim cards are small in size with removable memories and can hold a lot of data and number of identifications which are required to access any wireless service provider.the power consumption is usually less[14][15]

\begin{tabular}{|c|c|c|c|c|c|c|}
\hline & ZigBee & $\begin{array}{l}802.11 \\
(W i-F i)\end{array}$ & Bluetooth & $\begin{array}{l}\text { UWB (Ultra } \\
\text { Wide Band) }\end{array}$ & $\begin{array}{c}\text { Wireless } \\
\text { USB }\end{array}$ & IR Wireless \\
\hline Data Rate & $\begin{array}{l}20,40 \text {, and } \\
250 \mathrm{Kbits} / \mathrm{s}\end{array}$ & $\begin{array}{l}11 \& 54 \\
\text { Mbits/sec }\end{array}$ & $1 \mathrm{Mbits} / \mathrm{s}$ & $\begin{array}{l}100 \cdot 500 \\
\text { Mbits/5 }\end{array}$ & $62.5 \mathrm{Kbits} / \mathrm{s}$ & $\begin{array}{c}20-40 \mathrm{~Kb} t \mathrm{ts} / \mathrm{s} \\
115 \mathrm{Kbits} / \mathrm{s} \\
4816 \\
\mathrm{Mbits} / \mathrm{s}\end{array}$ \\
\hline Range & $\begin{array}{l}10-100 \\
\text { meters }\end{array}$ & $\begin{array}{l}50-100 \\
\text { meters }\end{array}$ & 10 meters & $<10$ meters & 10 meters & $\begin{array}{l}<10 \text { meters } \\
\text { (line of sight) }\end{array}$ \\
\hline $\begin{array}{l}\text { Networking } \\
\text { Topology }\end{array}$ & $\begin{array}{l}\text { Ad-hoc, peer } \\
\text { to peer, star, } \\
\text { or mesh }\end{array}$ & Point to hub & $\begin{array}{l}\text { Ad-hoc, very } \\
\text { small } \\
\text { networks }\end{array}$ & Point to point & Point to point & Point to point \\
\hline $\begin{array}{l}\text { Operating } \\
\text { Frequency }\end{array}$ & $\begin{array}{c}868 \mathrm{MHz} \\
\text { (Europe) } \\
900-928 \mathrm{MHz} \\
\text { (NA), } 2.4 \mathrm{GHz} \\
\text { (worldwide) }\end{array}$ & $\begin{array}{c}2.4 \text { and } 5 \\
\mathrm{GHz}\end{array}$ & $2.4 \mathrm{GHz}$ & $3.1 \cdot 10.6 \mathrm{GHz}$ & $2.4 \mathrm{GHz}$ & $800.900 \mathrm{~nm}$ \\
\hline $\begin{array}{l}\text { Complexity } \\
\text { (Device and } \\
\text { application } \\
\text { impact) }\end{array}$ & Low & High & High & Medium & Low & Low \\
\hline $\begin{array}{l}\text { Power } \\
\text { Consumption } \\
\text { (Battery option } \\
\text { and life) }\end{array}$ & $\begin{array}{l}\text { Very low (low } \\
\text { power is a } \\
\text { design goal) }\end{array}$ & High & Medium & Low & Low & Low \\
\hline Security & $\begin{array}{l}128 \text { AES plus } \\
\text { application } \\
\text { layer secunty }\end{array}$ & & $\begin{array}{l}64 \text { and } 128 \\
\text { bit encyption }\end{array}$ & & & \\
\hline $\begin{array}{l}\text { Other } \\
\text { Information }\end{array}$ & $\begin{array}{l}\text { Devices can } \\
\text { join an } \\
\text { existing } \\
\text { network in } \\
\text { under } 30 \mathrm{~ms}\end{array}$ & $\begin{array}{l}\text { Device } \\
\text { connection } \\
\text { requires } 3-5 \\
\text { seconds }\end{array}$ & $\begin{array}{l}\text { Device } \\
\text { connection } \\
\text { requires up to } \\
10 \text { seconds }\end{array}$ & & & \\
\hline $\begin{array}{l}\text { Typical } \\
\text { Applications }\end{array}$ & $\begin{array}{c}\text { Industrial } \\
\text { control and } \\
\text { monitoring, } \\
\text { sensor } \\
\text { networks, } \\
\text { building } \\
\text { automation, } \\
\text { home control } \\
\text { and } \\
\text { automation, }\end{array}$ & $\begin{array}{c}\text { Wireless LAN } \\
\text { connectivity, } \\
\text { broadband } \\
\text { Internet } \\
\text { access }\end{array}$ & $\begin{array}{c}\text { Wireless } \\
\text { connectivity } \\
\text { between } \\
\text { devices such } \\
\text { as phones, } \\
\text { PDA, laptops, } \\
\text { headsets }\end{array}$ & $\begin{array}{l}\text { Streaming } \\
\text { video, home } \\
\text { entertainment } \\
\text { applications }\end{array}$ & $\begin{array}{l}\text { PC peripheral } \\
\text { connections }\end{array}$ & $\begin{array}{c}\text { Remote } \\
\text { controls, PC, } \\
\text { POA, phone, } \\
\text { laptop links }\end{array}$ \\
\hline
\end{tabular}

\section{AVAILABLE SOFTWARES FOR STORAGE} AND TRANSMISSION

Thekeil[20] and embedded c++ compiler supports the microcontroller families embedded $\mathrm{c}++[20]$ is a subset of the $\mathrm{c}++$ programming language that is easy for $\mathrm{c}$ programmers to understand and use. the embedded c++ language satisfies the requirements of embedded software designs and avoids the overhead that is introduced eith full c++implementations [19 ]The primary advantages of these two softwares are Small language specification that retains object orientated features[15],avoids excessive memory consumption, produces predicable run time requirements, generates ROM able code, removes non standard extensions to c++ language features that are not authorized by ANSI/ISO are eliminated and the web applications for mobile phones or pc to the health provider in the super specialist hospital the best possible applications are DBMS preferably SQL data base[19]. 


\section{GLUCOMETERS AVAILABLE IN THE}

\section{MARKET [9]}

\begin{tabular}{|c|c|c|c|}
\hline Year & Development & Example & Company \\
\hline 1957 & Fist reagent strip using ducose oxidase reaction & Cinisitix & Ames \\
\hline 1964 & Modified reagent strip for blood gucose & Dextrostix & Ames \\
\hline 1970 & Reflectance photometry with Dextrostix & Ames Reflectance Meter & Ames \\
\hline 1973 & Mains-powered, single analogue scale & Eyetone & Ames \\
\hline 1974 & Reduced blood volume, stip wiping & Reflomat & Boehninger Manhneim \\
\hline 1980 & Digital display, whole blood standard & Dextometer & Ames \\
\hline 1980 & Automatic timing & GucocherevGucoscan & Lifescan \\
\hline 1981 & Improved countiooun timer with audio alam & Gucometer| & Ames \\
\hline 1981 & Stored calibration, lowhigh result alarms & Glucometer| & Ames \\
\hline 1986 & Data storage of results & Glucometer M & Ames \\
\hline 1987 & Non-wipe, automatic timing, 45-second measurement time test stip & OneTouch & Lifescan \\
\hline 1987 & First biosensor enzyme electrode sensors & Exactech & Medisense \\
\hline 1991 & Capilay-fill sampling with $5 \mu L$ blood & Hemocue & \\
\hline 1997 & Downloading results to personal computers & Gucometer Esprit & Bayer \\
\hline 2001 & Plasma calibration & OneTouch Utita & Johnson \& Johnson \\
\hline 2002 & Catering for visualy impaired persons & Acoucher Voicemate & Roche \\
\hline 2003 & Biosensor using coulometry, altemative site testing & Freestyle Freedom & Abbott \\
\hline 2003 & Autodisc of 10 strips replaced reagent strips & Ascensia Breeze & Baver \\
\hline 2005 & 17·test strip barrel & Acucheck Compact & Roche \\
\hline 2008 & Taking blood gucose meter & SensoCard Pus & $B B \mid$ \\
\hline
\end{tabular}

\section{CONCLUSIONS}

Based on the review done the best possible approach for the transmission enabled glucometer can be done by using the amperometric glucose sensors and GSM wireless technology and the softwareskeil,c++compiler and SQL data base are used for storage and transmission of data

\section{REFERENCES}

[1]. S. F. CLARKE and J. R. FOSTER History Committee, Institute of Biomedical Science, 12 Coldbath Square, London EC1R 5H

[2]. Mike Gidley, Peter Sopade, Ghaid Al-Rabadi, Barbara Williams and John BlackCentre for Nutrition and Food Sciences, The University of QueenslandSt Lucia 4072and John L Black Consulting, Locked Bag 21, Warrimoo 2774

[3]. New technologies for diabetes: a review of the present and the future Neesha Ramchandanil and Rubina A Heptulla1,2*

[4]. Continuous Glucose Monitoring Systems: A Review Sandeep Kumar Vashist HSG-IMIT-InstitutfürMikro-und Informationstechnik, Georges-Koehler-Allee

[5]. Self-Monitoring Blood Glucose Test Systems for OvertheCounterUseU.S. Department of Health and Human Services Food and Drug Administration Center for Devices and Radiological Health Office of In Vitro Diagnostic Device Evaluation and Radiological Health Division of Chemistry and Toxicology Devices
[6]. Use of glucometer and fasting blood glucose as screening tools for diabetes mellitus type 2 and glycated haemoglobin as clinical reference in rural community primary care settings of a middle income country Benja Muktabhant1, Pattara Sanchaisuriya1, Pongdech Sarakarn2, Worawitaya Tawityanon3, Mantana Trakulwong3,Songsri Worawat3, and Frank P Schelp 4*

[7]. Type 1 diabetes in adults: national clinical guideline for diagnosis and management

[8]. Electrochemical Glucose BiosensorsJoseph Wang* Biodesign Institute, Center for Bioelectronics and Biosensors, Departments of Chemical Engineering and Chemistry and Biochemistry

[9]. Glucose Biosensors: 40 Years of Advances and Challenges Joseph Wang* Department of Chemistry and Biochemistry, New Mexico State University, Las Cruces, NM 88003, USA;

[10]. Investigations of foliage effect on modern wireless communication systems: a review y. s. meng,y. h. lee

[11]. Future Electronics Egypt Ltd. (Arduino Egypt)

[12]. A Review On Improving Technologies In Wireless Communications Parasa Sri Sai Chaitanya\#1, Suresh Angadi*2\# Final Year B.Tech, Dept. Of ECE, K L University, Vaddeswaram, Guntur, AP, India.*Asst.professor in ECE Dept., $\mathrm{K}$ L University, Vaddeswaram, Guntur, AP, India

[13]. A Comparative Study ofWirelessProtocols:Bluetooth, UWB, ZigBee, and Wi-Fi Jin-Shyan Lee, Yu-Wei Su, and Chung-Chou Shen Information \&Communications Research Labs Industrial Technology Research Institute (ITRI) Hsinchu, Taiwan

[14]. Communication Technologies and their Applications beyond Communication Simon Mayer Department of Computer Science, ETH Zurich

[15]. IJCSI International Journal of Computer Science Issues,July 2011

[16]. a) D. Gough, J. Lucisano, P. Tse, Anal. Chem. 1985, 57, 2351b) J. Armour, J. Lucisano, D. Gough,Diabetes1990, $39,1519$.

[17]. Goldstein DE, Little RR, Lorenz RA, Malone JI, Nathan D, Peterson CM:Tests of glycemia in diabetes.Diabetes Care1995,

[18]. Simmons RK, Unwin N, Griffin SJ:International Diabetes Federation: An update of the evidence concerning the prevention of type 2 diabetes.Diabetes Res Clin Pract2010,

[19]. DBMS in bioinformatics

[20]. www.Embedded softwares.com 